\title{
Clinical legal education: Interviewing skills
}

M A (Riëtte) du Plessis

$B A L L B L L M$ PhD

Associate Professor, University of the Witwatersrand, Johannesburg

\section{OPSOMMING \\ Kliniese regsopleiding: Vaardighede in onderhoudsvoering}

Vaardigheidsopleiding, wat onderhoudsvoering insluit, is aanvullend tot 'n kliniek se oogmerk van sosiale geregtigheid, aangesien dit studente bemagtig om uitspraak uit te stel, om vanoor 'n verskeidenheid te kommunikeer en oplossings te soek. Onderhoudsvoeringvaardighede is 'n basis van kliniese regsopleiding, 'n leermetode in 'n lewende-kliënt kliniek. Aangesien studente oor die algemeen sonder kliniese toesig onderhoude voer, is hul opleiding in die verband noodsaaklik. In die bespreking van onderhoudsvoeringopleiding, val die klem op die voorbereiding van studente, wat die taking van vooropgestelde idees en aannames insluit, asook beradingsvaardighede. 'n Verskeidenheid van ondervragingstegnieke word bespreek en daar word aangedui dat onderrigliteratuur die veronderstelling ondersteun dat die manier waarop vrae gestapel word belangriker mag wees vir die bevordering van begrip as die kognitiewe vlak van die vraag. Periodieke opsommings help die studente om 'n beter begrip van die sake te vorm. 'n Bondeling van optredes wat binne konteks geïnterpreteer moet word, is nie-verbale aanduidings, gedrag wat obstuksies tussen die studente en hul kliënte mag vorm, spieëlgedrag en prosedie. Regsanalise en strategieë met potensiële oplossings waarvoor studente verantwoordelikheid moet aanvaar, aangesien hulle handelinge andere mag beïnvloed, word bespreek. Die doelstellings van kliniese regsopleiding, soos van toepassing op onderhoudsvoering, word aangedui.

\section{Introduction}

In live-client university law clinics students interview and advise clients. Clinical legal education (CLE) is the teaching methodology applied in clinical courses. ${ }^{1}$ Client interviewing forms part of the main goals or outcomes identified for CLE. ${ }^{2}$ Interviewing skills were identified as an

1 Quigley 'Introduction to clinical teaching for the new clinical law professor: a view from the first floor' (1995) Akron Law Review 463.

2 Steenhuisen in De Klerk et al Clinical law in SA (2006) 266-279. Seven main goals (outcomes), each with their own sub-goals were identified. The following are associated with the sub-goal of consultation skills: professional responsibility, legal ethics, personal norms/morality, professionalism, social awareness, judgment and analytical abilities, recognition of relevant facts and applicable law, understanding strategy, tactics, decision making, process, procedure, substantive law, client counselling, legal research, factual investigation and legal services to the community. 
essential skill across a number of jurisdictions, ${ }^{3}$ including South Africa. ${ }^{4}$

Although clinicians are present or generally available in the clinic whilst students are conducting interviews with clients, ${ }^{5}$ they are seldom a party to such interviews. ${ }^{6}$ The majority of scholars opine that students should conduct client interviews without clinician supervision. ${ }^{7}$ Input by the clinician is however required before clients are advised. ${ }^{8}$ As students generally start interviewing clients early on in their clinical course, ${ }^{9}$ it is essential that students are trained and instructed in this essential skill, which must meet the CLE course outcomes. ${ }^{10}$

In the law clinic students need to have conversations with clients to learn the facts relating to their legal problems. Only then substantive law will be analysed and applied to the legal problem. When students are preparing for interviews, they have to be cognisant of any preconceptions and assumptions they may have about their clients. ${ }^{11}$

In discussing the interview, the focus will be on note-taking, questioning techniques and non-verbal cues as clusters of behaviours to be interpreted within context. ${ }^{12}$ Legal analysis and strategy will be

3 Du Plessis Clinical legal education: Law Clinic Curriculum design and assessment tools (2016) 47, 48.

4 Ibid; Haupt in De Klerk et al Clinical law in SA (2006) 55 - 71.

5 Clinicians are focused on directing all the attending students on how clients are to be serviced after students relay clients' legal problems to them. Du Plessis 123

6 Du Plessis supra n3 at 122, 41-44. It is impossible for clinicians to attend all interviews.

7 ACLE 2017 (Australian Clinical Legal Education), available at http://press. anu.edu.au/publications/australian-clinical-legal-education 144 (accessed 2018-06-01). They however cautioned that the best model no doubt depends on the individuals involved, that is, both the supervisor and the student. 'Students should be prepared for their work with real clients by observing and discussing interviews, advocacy activities and other client work conducted by practitioners'.

8 Interviews are also conducted without direct supervision in e.g. England and Australia. Du Plessis supra n3 at 128, 129; Brayne in Webb and Maughan Teaching Lawyers' Skills (1996) 173

9 As in South Africa from the early 1970s, see De Klerk et al Clinical law in SA (2006) 264. Students at Monash, Australia consult independently within a few weeks from the start of their clinical course, see Evans \& Hyams 'Independent evaluations of clinical education programs: Appropriate objectives and processes in an Australian setting' 2008 Griffith Law Review 60. See Du Plessis supra n3 at 16, 17 for current statistics at South African law clinics.

10 Schrag 'Constructing a clinic' 1996 Clinical Law Review 175, 180-85; see also Babich 'The Apolitical Clinic' 2004 Tulane Lawyer 10; Du Plessis supra n3 at 32, 33.

11 Salinas Effective client interviewing and counselling (2016) 21, 175; UWE supra n11 at Bristol (University of West England, Bristol) 2012-2013. Legal Practice Course, available at www2.uwe.ac.uk/services/Marketing/students/ Newstudents/Ch2-Lawyers-Skills.pdf (accessed 2014-06-02) 8; Tremblay 'Interviewing and counseling across cultures: Heuristics and biases' Clinical Law Review 2002373.

12 UWE supra n11 at 7. This will include a discussion on prosody. 
discussed, ${ }^{13}$ with potential solutions to be found by way of legal and nonlegal options, ${ }^{14}$ as well as the identification of further steps and the ending of an interview. ${ }^{15}$ The final consideration will be whether the proposed CLE outcomes, applicable to interviewing skills, were met.

\section{Clinical legal education: Skills and outcomes}

O'Regan J stated that the lives of law graduates 'are determined in a real sense by the skills and habits that they have acquired at law school' and that 'much of the test of what constitutes a competent lawyer is skillsbased rather than content-based'. ${ }^{16}$

Interviewing skills, or, as often referred to as consultation skills, were among the essential skills identified in research across a number of jurisdictions. ${ }^{17}$ In synergy are the identified skills of ethics, the capacity to deal sensitively and effectively with clients from a range of social, economic and ethnic backgrounds and disabilities, effective communication techniques, recognition of clients' financial, commercial and personal constraints and priorities, effective problem-solving, legal research, time and risk management, to recognise personal strengths and weaknesses, legal analysis and reasoning, factual investigation and counseling skills. ${ }^{18}$ These skills are all associated with interviewing skills and form part of the interviewing process. The results of a three year Australian project shows, in focusing on skills associated with interviewing skills, that the following additional skills are developed: ${ }^{19}$

[A]ccepting and assuming responsibility for matters of great importance to real clients, improving problem-solving abilities, discovering facts and figuring out how to turn them into admissible evidence, and 'traditional skills' such as interviewing, case planning, investigating facts, counseling, legal writing, witness examination, oral argument, legal professionalism, such as values and ethics, ${ }^{20}$ and strengthening students' emotional awareness and sense of ethical behaviour. ${ }^{21}$ During the interviewing process, the CLE teaching

13 Salinas supra $\mathrm{n} 11$ at $98,110-112,138,142$.

14 Idem at $145-150$.

15 Idem at 54; UWE supra $\mathrm{n} 11$ at 23.

16 O'Regan 'Producing competent graduates: The primary social responsibility of law schools' 2002 SALJ 247.

17 Du Plessis supran3 at 35.

18 Du Plessis supra 3 at 34 - 37; For detail in the South African environment, see De Klerk (2006) 29 - 262 and specifically Haupt $55-71$.

19 ACLE supra $\mathrm{n} 7$ at 74.

20 Schrag supra n20 at 183-184; see also Curran, Dickson and Noone 'Pushing the boundaries or preserving the status quo? Designing clinical programs to teach law students a deep understanding of ethical practice' 2005 International Journal of Clinical Legal Education 104; Kerrigan 'How do you feel about this client?' A commentary on the clinical model as a vehicle for teaching ethics to law students' 2007 International Journal of Clinical Legal Education 37; Cody at 'What does legal ethics teaching gain, if anything, from including a clinical component?' 2015 International Journal of Clinical Legal Education 1.

21 Cody supra n20 at 1. 
method can meet the aims of personal and professional development such as, for example, cross-cultural awareness, the role of emotions, creativity, exercising authority and learning to learn. ${ }^{22}$

Learning outcomes for the basic skills and processes involved in interviewing and advising clients were suggested as, on completion, students should be able to:

state the purpose of the client interview; use all information-seeking techniques confidently; listen actively and respond with appropriate follow-up to what you have heard; summarise information to check understanding; structure an interview so that necessary information is acquired and given; give appropriate advice to the client; and state the processes whereby rapport with clients can be developed. ${ }^{23}$

\section{Supervising student interviews}

In South Africa, there is a lack of supervision capacity during interviews due to the large student numbers in proportion to available clinicians. ${ }^{24}$ The lack of direct supervision during interviews need however not be insurmountable. Opinions on student supervision during interviews vary. Australian research observed that the clinic at the University of New South Wales emphasised direct supervision of students during the first interview. ${ }^{25}$ Clinical programmes outside New South Wales tend to use the approach developed at Monash 'whereby the student, after taking the client's instructions and consulting with the supervisor, returns to the client and advises them, unaccompanied by their supervisor'. 26

Givelber indicates that there is 'absolutely no empirical support' that learning can only occur under professional supervision. ${ }^{27}$ English clinical scholar Hugh Brayne indicates that for his first four years as a clinical supervisor, he 'sat in on every student interview', thinking 'that I had a professional responsibility to do so'. ${ }^{28}$ After discussions with clinicians in the United States, he hardly ever sat in on student-client interviews, avoiding usurping the student's relationship with the client. Brayne indicated that his previous approach had come from 'a failure to separate the two goals of legal service and student learning'. ${ }^{29}$ Australian researchers noted Brayne's argument, in favour of allowing students to

22 Schrag supra n20 at 182, 184-185.

23 UWE supra $\mathrm{n} 11$ at 26.

24 Du Plessis supra n3 at 109

25 ACLE supra 7 at 136.

26 This procedure is also followed at the Wits Law Clinic, see Du Plessis supra n3 at 27.

27 Givelber, Baker, McDevitt and Miliano 'Learning through work: an empirical study of legal internships' 1995 Journal of Legal Education 1, 3. They however found that "both the characteristics of the job and the presence of supervision play important roles in students' evaluations of their work experiences'.

28 Brayne supra n8 at $172-173$.

29 Ibid. 
conduct their interviews and provide advice without their supervisor present, persuasive. ${ }^{30}$

\section{Preparing students for interviews with clients}

Where students are conducting interviews without direct supervision, ${ }^{31}$ student preparation and instruction are essential. Students will meet with a client who will present them with a problem. The client will need assistance in having the problem solved. During a client interview students have to ask themselves certain questions, such as: 'what is the client's question that I am being asked to answer?'; 'What information do I have available to help me answer the question?'; What information do I need to get from the client to help me answer the question?' During an interview, students have to talk to the client to get the information in order to enable them to answer the questions. ${ }^{32}$

The information gained from the client constitutes the facts of the legal problem. Students then need to apply the law to the information. From the legal analysis, an answer can be communicated to the client. 33 Taking a problem-solving approach is therefore as important in the student-supervisor relationship as it is in the student-client relationship. ${ }^{34}$ Students need to appreciate the central significance of their clients, ${ }^{35}$ building a bridge to a strong professional relationship, facilitated by effective interviewing and client counselling skills. ${ }^{36}$

\section{Working with preconceptions and assumptions}

In preparing for the interview, students must not make any assumptions about the client's knowledge or the emotional impact the case may have. They must not assume that the client will be willing to accept certain risks, or even that the client's case is capable of a legal resolution. ${ }^{37}$ In teaching interviewing skills, students' possible stereotypical views must be addressed. ${ }^{38}$ such as 'the effects of race, class and ... gender on the

30 ACLE supra $\mathrm{n} 7$ at 144 . They however cautioned that the best model no doubt depends on the individuals involved, that is, both the supervisor and the student. 'Students should be prepared for their work with real clients by observing and discussing interviews, advocacy activities and other client work conducted by practitioners'.

31 Du Plessis supra n3 at 27-29. The clinician is not attending the interview, but is present in the clinic for student consultation.

32 Salinas supra $n 11$ at 12,14

33 Ibid. The details of the problem will generally first be discussed with the supervisor before the client is advised.

34 ACLE supra $\mathrm{n} 7$ at 150,151 . Students should expect to receive clear instructions from their supervisors rather than have their supervisors provide them with answers.

35 Ibid

36 Salinas supra $\mathrm{n} 11$ at 21.

37 UWE supra n11 at 8.

38 See Tremblay supra $n 11$ at 373. 
interaction between lawyer and client, ${ }^{39}$ cognisance of cultural, age or factual differences, ${ }^{40}$ and to adhere to some basic cultural protocols. ${ }^{41}$ Failure may result in clients withholding certain information from the students, making advising difficult. ${ }^{42}$ The teaching of diversity issues in preparing students for interviews is therefore essential.

Bryant developed 'the five habits of cross-culture lawyering' ${ }^{43}$ In brief, habit one provides students with a framework within which to analyse how similarities and differences between the lawyer and client may influence lawyer-client interactions, ${ }^{44}$ as these might affect students' abilities to understand clients and to form relationships with them as lawyers. ${ }^{45}$ In terms of habit two students are asked to identify and analyse the possible effects of similarities and differences on the interaction between the client, the legal decision-maker (e.g. the Judge or magistrate) and the lawyer. ${ }^{46}$ Habit three teaches students a method for exploring alternative explanations for clients' behaviours. The habit of 'parallel universes' thinking invites students to look for multiple interpretations, especially at times when the student is judging the client negatively. ${ }^{47}$ Habit four focuses on cross-cultural communication, identifying some tasks in normal attorney-client interaction that may be

39 Jacobs 'People from the footnotes: the missing element in client-centered counselling' Golden Gate University Law Review 345, 346.

40 Salinas supra 11 at 175 . The term 'flavour' may mean salty or spicy to one, as opposed to meaning bland or mild to someone else. Clients maintaining good eye contact whilst speaking may indicate to the students 'that they are being attentive and speaking honestly. However, for some cultures, maintaining eye contact may be an indication of disrespect'. Also see Du Plessis supra n3 at 124-128, 132-135 for a full discussion of language barriers, fear, racial, cultural and religious differences as student challenges during interviews.

41 Du Plessis supra n3 at 125-135. Some clients consult from, often rural, areas where certain customs are strictly adhered to, often causing an inability to distinguish between cultural or indigenous customs, religious practices and the law regulating the society. For a discussion of how these are addressed in Australia, see Cody supra n20 at \& Green 'Clinical legal education and Indigenous legal education: what's the connection?' 2007 International Journal of Clinical Legal Education 51-64.

42 For a full discussion see Du Plessis supra n3 at 125-135. Cultural custom may prevent clients from discussing details about money, particularly with females, strangers or people younger than them; in some cultures family ties are formed that do not correlate with the concept of a family in a legal sense; and confusion around language expression.

43 Bryant supra n43 at 'The five habits: building cross-cultural competence in lawyers' 2001 Clinical Law Review 1-62.

44 Ibid. Habit One: Degrees Of Separation And Connection. Students are asked to list and diagram similarities and differences between themselves and their clients. Differences create the possibility of cultural misunderstanding, bias and stereotyping. Similarities illustrate the connections between students and clients.

45 Bryant supra n43 at 13. Students are made aware that culture is dynamic and the importance of different identities changes as the situation changes. See pp 14-15 for a discussion of the Venn diagram.

46 Habit Two: The Three Rings. Bryant supra n43 at 15-16 for a discussion of this habit.

47 Idem at 16, 17. Habit Three: Parallel Universes. 
particularly problematic in cross-cultural encounters as well as alerting students to signs of communication problems. ${ }^{48}$ Habit five involves exploring one-self as a cultural being. Students must face the sometimes ugly side of cultural blinders - bias and stereotype. ${ }^{49}$ The application of these habits during cross-culture interviewing may assist students in developing impartial interviewing skills, enabling them to address any of their own preconceptions and assumptions regarding a client. Application may furthermore be beneficial during student reflection when their interviewing skills are assessed. ${ }^{50}$

\section{Interview preparation}

Students must proactively try to counter any possible distractions they anticipate. $^{51}$ Clients are frustrated when students are distracted, inattentive or side-tracked, which may affect their confidence and comfort with complete disclosure of the facts relating to their cases. ${ }^{52}$ If possible within the clinical setting, clients must be seated to limit any power dynamic. ${ }^{53}$ A circular table interview, as opposed to students and clients sitting on opposite sides of a desk would be ideal. Clinical settings however seldom support this ideal. Power dynamic can, however, be limited when students refrain from displaying personal items such as laptops, cell phones, any indulgent personal items or their own coffee and snacks. Students should also not take any incoming phone calls, especially not making comments such as, for example: 'My apologies, but this call is really important' during the interview.

Physical barriers, such as open laptops or stacks of files on the desk, create distance between the interviewing students and the clients, making them feel less connected, or intimidated and less likely to open up to the attorney-client relationship. ${ }^{54}$ In order to avoid distractions, clients should not be seated facing the door or a corridor where people are passing by during interviews.

Students may prepare a roadmap, ensuring that the interview has a logical sequence and structure without being too rigid. A short roadmap of what the interview will look like and an outline of what should be covered will assist new and inexperienced clients with their

48 Idem at 17-19. Habit Four: Pitfalls, Red Flags And Remedies.

49 Idem at 19. Habit Five: The Camel's Back. Students are encouraged to create settings in which bias and stereotype are less likely to govern, promoting reflection and change of perspectives with a goal of eliminating bias. It recognises innumerable factors that interact with bias and stereotype to negatively influence an attorney-client interaction

50 See Du Plessis supra n3 at 131-132 for a discussion on students' reflective journals in assessing students' interviewing skills.

51 Salinas supra $\mathrm{n} 11$ at 167; UWE supra $\mathrm{n} 11$ at 9.

52 Salinas supra $n 11$ at 166. See Lauchland $\dot{\&}$ Le Brun Legal Interviewing Theory, Tactics and Techniques (1996) 70 for a full discussion.

53 Salinas supra n11 at 118; UWE supra n11 at 9.

54 UWE supra $\mathrm{n} 11$ at 9 
understanding and expectations. ${ }^{55}$ Roadmaps will differ depending on whether the client is attending a first or subsequent interview. At the start of an initial interview, students may present the following roadmap to the clients: the interview will start with the discussion of administrative items, whereafter the students will explain professional responsibility, confidentiality and conflicts of interest to the clients. The client will then have the opportunity to tell his or her story, explaining the facts of the case. The students will thereafter summarise the facts the client presented and discuss some legal issues that were identified. The students may thereafter discuss some initial possible solutions to the client's legal situation, including legal and non-legal options they may want to explore. ${ }^{56}$ The interview may thereafter come to end by students providing the client with a short summary of the main points of the interview, as well as discussing further steps to be pursued in the next few weeks. ${ }^{57}$

\section{Conducting the interview}

\section{Note-taking}

Note-taking skills are important for students in establishing them as effective interviewers and they must explain the need to take notes to their clients. ${ }^{58}$ Students will have to, when action is taken after the interview, rely on accurate notes, ${ }^{59}$ preferably taken by hand. Psychological studies on the effectiveness of different styles of notetaking ${ }^{60}$ found that laptop users did relatively well on factual questions, but fell short on conceptual questions which involve comparing and analysing the information gleaned. ${ }^{61}$ When the interviewer types on a keyboard, the tendency to describe, verbatim, what he or she hears is very strong. A laptop screen is furthermore a physical barrier between the student and the client. When the student looks at the laptop instead of the client, it sends the message that the student is not listening. As the application of facts to the law is conceptual, it was concluded that

55 Salinas supra $\mathrm{n} 11$ at 123-127. Clients will have a better understanding of what to expect during the interview. The speed and level of sophistication will depend on clients' levels of education and whether they are familiar with the attorney-client relationship. Also see Lauchland \& Le Brun supra n52 at 82.

56 It is important that the client is informed that the facts and possible legal solutions will first be discussed with the clinician in attendance.

57 Salinas supra $\mathrm{n} 11$ at $98-103$

58 UWE supra $\mathrm{n} 11$ at 24 . It was suggested that ' $\mathrm{n}$ ] othing is more off-putting to a client than the sudden scribbling down of something they have just said. On the other hand, you need to be able to recall accurately the details of the interview'. Also see Lauchland \& Le Brun supra n52 at 101.

59 UWE supra n11 at 24. Having to go back to clients asking for information they have already given, may irritate clients and is unprofessional.

60 Glover 'Lawyers Should Take Notes by Hand' available at https:// lawyerist.com/lawyers-take-notes-hand/ (accessed 2018-06-14).

61 Ibid. 
attorneys, and therefore students, should take notes by hand. ${ }^{62}$ Taking notes with pen and paper whilst actively listening to the client may possibly generate better questions and improve retention of information. 63

It is suggested that, ${ }^{64}$ during the interview, students should take a 'listen first' approach by actively listening to the client's story. During each stage of the interview, students should confirm their understanding of the information, whereafter they can note it down. At the end of the interview, students should use their notes to summarise the information, confirming its accuracy with the clients. ${ }^{65}$

\section{The interview}

Students must be confident when greeting the client, ${ }^{66}$ observing their non-verbal communication. They should open the conversation with some initial, uncontroversial, but short small talk, ${ }^{67}$ letting the client know that they are there to help. ${ }^{68}$ For many clients it will be their first experience with an attorney, some having pre-conceived ideas or misconceptions. When clients feel uncared for, they may withhold significant facts or forget to give information. The initial meeting will set the tone for the rest of the interview, as the first few minutes will be significant in establishing a strong professional relationship. Before the actual interview starts, clients must be made aware of matters impacting the attorney-client relationship, such as confidentiality, legal professional privilege and conflict of interest. ${ }^{69}$

$62 \mathrm{Ibid}$. The study found that when the interviewer takes notes by hand, he or she has to pay attention and decide what is important.

63 A recommended note-taking methodology is the Cornell Note-Taking System whereby, in short, a page is divided into unequally sized quadrants, with one quadrant for notes, one for key points and one for a summary, forcing a review and summary of notes. The fourth quadrant is given over to 'next actions,' essentially the to-do's that result from the meeting. See Cornell University 'The Cornell Note-taking System' available at http:// 1sc.cornell.edu/study-skills/cornell-note-taking-system/ (accessed 2018-0614).

64 UWE supra $\mathrm{n} 11$ at 24.

65 Ibid. Soon after the interview, students should write up their notes clearly and accurately, as notes taken at the time may serve their short term memory well, but may cause them problems if they have to rely on them days or even weeks later.

66 Before the interview starts, attorneys usually deal with administrative items. Salinas supra n11 at 115. I accept, for purposes of this article, that paralegals or other designated law clinic staff attend to these prior to the interview with the students.

67 UWE supra n11 at 10; Malkus, Stevenson \& Williams 'Engaging students for transactional practice' 2011 Institute for Law Teaching and Learning Conference New York Conference paper 1 - 10.

68 Ibid 31; Salinas supra 111 at 32-34.

69 Salinas supra n11 at 117-119; Lauchland \& Le Brun supra n52 at 152- 163. 
The continuum of most interviews is that, in one way it can be conducted as an interrogation, ${ }^{70}$ and in another way it can be conducted as a free-flowing two-way conversation. ${ }^{71}$ Students must not feel compelled to force the client to speak right away, but acknowledge the client's concerns about the legal problem, whilst establishing rapport, ${ }^{72}$ and letting clients know that what they say is important and that the students' opportunities for application of the law to the facts of the case will follow later. What is required of the students is to pay attention, knowing that the client is just as important as their educational goals. ${ }^{73}$ Clients must be allowed to explain matters in their own words, expressing their feelings, as if in conversation. Clients must not be put on the defense at the start of the interview with questions such as 'Is that true?', thereby erasing any prior established rapport. This may also confuse clients or make them anxious. ${ }^{74}$ Students must heed their tone of voice, especially in establishing trust and rapport. When the tone is too forceful, clients may misinterpret what is being said. With the correct tone of voice, the student encourages the client to be as open and honest as possible, providing the necessary information needed for the case. Clients can also be discouraged when what students say does not correspond with their non-verbal communication. ${ }^{75}$

\section{Questioning methods}

General education literature supports the premise that the way in which questions are sequenced may be more important in promoting understanding than the cognition level of the question. ${ }^{76}$ Appropriate sequencing of questions allows the students and clients to focus first on the fundamental aspects of the legal problem that is discussed. ${ }^{77}$

A number of key questions, each with a purpose to elicit information from the client, can be applied. A variety of question types may be used in each interview, the appropriateness of which may vary during the different phases of the interview. ${ }^{78}$

To encourage clients to speak, students should use open-ended questions which will allow clients to describe the problems as they see

70 In an interrogation, one of the parties is an unwilling participant where the agenda is totally controlled by the interrogator. UWE supra $\mathrm{n} 11$ at 11 .

71 In a free-flowing conversation, both parties are willing to communicate and do so openly. UWE supra n11 at 11 .

72 'Rapport' described in the Cambridge English dictionary as having a good understanding of someone and an ability to communicate well with them. See 'Rapport', available at https://dictionary.cambridge.org/ dictionary/english/rapport (accessed 2018-06-01); also see Lauchland \& Le Brun supra $\mathrm{n} 52$ at $78-81$; ACLE supra $\mathrm{n} 7$ at 163.

73 Salinas supra 111 at $40-48$.

74 Ibid.

75 Maranville:https://courses.washington.edu/civpro03/resources/ interviewing.doc; Salinas supra n11 at 49, 51 .

76 Brophy \& Good Third Handbook of Research on Teaching (1987) 189-193.

77 Ibid.

78 Lauchland \& Le Brun supra n52 at 54. 
it. ${ }^{79}$ Open-ended questions are the 'what', 'why', 'how', 'when', 'where' questions that are impossible to answer in a single word or with a shrug, ${ }^{80}$ prompting clients have to construct the answers in their own words. ${ }^{81}$ During this phase, students should rather take notes of details requiring clarification than interrupting clients. ${ }^{82}$

They should summarise periodically to confirm their understanding and encourage clients to correct any misunderstandings. ${ }^{83}$ Students should not be afraid of silence, as clients often need time to think a response through, or they may battle to find the right words to explain themselves. When students fill the silence with another question in encouragement, which is often close-ended, they not only restrict the available answers, but limit clients' opportunity to use their own words. $^{84}$

During the initial stages of the interview clients will be discouraged from talking when students use close-ended-, narrowing-, multiple choice- or leading questions. Close-ended questions require only 'yes' or 'no' or 'don't know' answers, or require very specific information, 85 limiting the scope of the answer. ${ }^{86}$ Close-ended questions pass the initiative to the students, tempting them to frame the situation in their terms, constructing an interpretation which differs from that of the clients, ${ }^{87}$ essentially highlighting to the clients what the relevant facts of the case should be, even before hearing all the facts from the clients. ${ }^{88}$ Clients may not relay highly relevant information or disregard important facts as students did not specifically ask questions relating thereto, leading to assumptions about the case. ${ }^{89}$ Close-ended- or clarifying questions can be asked later, pertaining to specific detail, or to focus on relevant legal issues or sift through some peripheral information. ${ }^{90}$

79 Salinas supra 11 at 130.

80 For example, 'What happened?' 'Why did you think that?'. UWE supra n11 at 11 . More ways to ask an open-ended question without really asking a question are 'Tell me more', 'I see', 'Go on', 'Help me understand a little more about what may have happened' see Salinas supra n11 at 171 . Also see Lauchland \& Le Brun supra n52 at 54, 95.

81 Salinas supra $\mathrm{n} 11$ at 58, 81; UWE supra n11 at 11; Lauchland \& Le Brun supra $\mathrm{n} 52$ at 54.

82 Interruption is also referred to as verbal tracking. For a discussion, see Lauchland \& Le Brun supra $\mathrm{n} 52$ at 56.

83 Ways to address clients are: 'So the situation so far is that ..., 'Have I got that right?' UWE supra n11 at 11. A full summary of the factual information should be relayed back to the client in reflection at the end of the interview. See Salinas supra n11 at 132.

84 UWE supra $\mathrm{n} 11$ at 11 ; Salinas supra $\mathrm{n} 11$ at 38.

$85 \mathrm{Ibid}$. Examples of close-ended questions requiring specific information may be, for example: 'So, you were in an accident?'; 'Was this raining?'

86 Lauchland \& Le Brun supra n52 at 54.

87 UWE supra 11 at 12

88 Salinas supra 11 at 59.

89 Idem at 56, 59, 130.

90 Salinas supra n11 at 171; Lauchland \& Le Brun supra n52 at 55. 
Multiple choice questions, like close-ended questions, allow for a very restricted range of possible responses. These are questions such as: 'Do you want compensation or your job back or both?" 91 The same objections, as stated for close-ended questions, apply.

Leading questions expect a particular answer and suggest to clients that the students already formed an interpretation of events which may not be the same as theirs, but that they are invited to agree with the interpretation. ${ }^{92}$

Value-laden questions may often be careless phrasing which may affect the client's recall and should be avoided. For example: a client should be asked to describe an assailant rather than asking a question such as "how big was he?" 93

During the decision-making phase, students may use hypothetical questions, such as 'if you are offered a settlement, then ...?'94 By asking this type of question, students put propositions to the client to test his or her responses.

Funnelling may be used in subsequent interviews. The funnelling method of interviewing is a technique commonly used in the experiential education setting where the processing of information is done in a very specific sequence and can be used when more detail in a discussion needs to be developed. ${ }^{95}$ The students will start by asking a general open question, preferably relating to facts, prompting clients to regurgitate basic facts they already know. ${ }^{96}$ This is followed up by asking about the context of the problem scenario ('who', 'when', 'where'). ${ }^{97}$ Further questions ('how', 'why') explore the dynamics of the problem scenario. ${ }^{98}$ Finally, the students can confirm their understanding by using closeended questions. The inverted funnel, where 'the sequencing of questions begins with very closed questions and gradually opens out to embrace wider issues'99 is useful when advising clients when they have to decide on the action to be taken.

91 UWE supra n11 at 12 .

92 Ibid; Lauchland \& Le Brun supra n52 at 54. 'Leading questions suggest answers and thus pose the risk for distorting the client's answer and promoting unethical behaviour by the lawyer. See Maranville:https:// courses.washington.edu/civpro03/resources/interviewing.doc

93 Lauchland \& Le Brun supra n52 at 55.

94 Ibid.

95 Barnum 'Questioning skills demonstrated by approved clinical instructors during clinical field experiences’ 2008 Journal of Athletic Training 284-292. 'The critical factor in funnelling is the need to listen to what your client is telling you. Only when you do this can you ask further questions effectively: See UWE supra $\mathrm{n} 11$ at 12.

96 Idem at 284-292.

97 Ibid.

98 UWE supra n11 at 9. 'How' questions make clients apply what they know. 'Why' questions help clients synthesize and analyse the situation.

99 UWE supra n11 at 9,10. 


\section{Non-verbal communication}

Non-verbal communication consists of a combination of eye-contact, posture, facial expressions, gestures, relative positions and touch. ${ }^{100}$ For example: do clients look away when detailing a particular fact? Do they slouch? Are they covering part of their face with their arm? Do they smile, laugh, tremble? These may be as important as the facts, providing more meaning to what has already been told. Students should caution not to presume to automatically understand nonverbal behaviour and should be confident that they are reading it correctly. They must be cognisant of cultural, age or factual differences. Certain non-verbal communication is universal: smiling, frowning or scowling, whilst others are culturally determined. 'The thumbs-up, the V-sign and degrees of proximity are interpreted differently in different cultures. ${ }^{101}$ The strength of the message from non-verbal communication is many times stronger than that from words alone. ${ }^{102}$ Students may mirror some of the clients' nonverbal behaviour as a technique to help build trust and rapport, helping to put clients at ease, as they might feel a non-verbal connection. ${ }^{103}$ For example, when clients speak in a soft tone of voice, students should speak back to clients in the same tone. Barriers can be created when students respond loudly and aggressively. Mirroring that works include: when clients lean forward in their chairs, it may be an indication of wanting to be heard and regard that what they are say as important. Students should also lean forward. Students should not mirror clients' behaviour when they speak angrily or scream, but talk back calmly. 104

\section{Clusters, context and congruence}

Non-verbal communication and behaviours should not be seen as individual, isolated signals, but as clusters of behaviours, meaning that several behaviours in combination will reinforce the non-verbal message. ${ }^{105}$ For example: a client's 'posture, positioning of arms, legs, hands and fingers, combined with facial expression, all contribute to the sense that this is a person listening critically to what is being communicated to them'. ${ }^{106}$ Non-verbal behaviour must be interpreted within context. ${ }^{107}$ For example: a client sits trembling while describing witnessing an attack, causing students to think she is reliving it, whilst

100 UWE supra n11 at 6; Salinas supra n11 at 175.

101 Salinas supra $\mathrm{n} 11$ at 175 ; UWE supra 11 at 6.

102 UWE supra n11 at 7 where reference is made to a patient of Freud's who initially spoke positively about her marriage, whilst unconsciously slipping her wedding ring on and off her finger. Later discussions brought out her underlying unhappiness in her marriage.

103 Salinas supra $\mathrm{n} 11$ at $175-177$.

104 Ibid.

105 For discussion and examples, see Pease The Definitive Book of Body 106 Ibid. Language (2005); UWE supra n11 at 6.

107 UWE supra $\mathrm{n} 11$ at 6. 
she in fact just feels cold. ${ }^{108}$ Congruence entails that the non-verbal communication behaviours must be consistent with the other aspects of communication. ${ }^{109}$ For example: 'If two people are shouting, and their non-verbal cues are angry and aggressive, we are entitled to infer that they are angry and aggressive. If the same scene involved the participants' laughing, we would have to interpret it differently'. 110

\section{Prosody}

Meaning can be added to communication by making use of non-word sounds such as grunts or sighs. ${ }^{111}$ Prosody is when these are combined with pauses, changes in pitch, rhythm and stress. ${ }^{112}$

\section{Active listening}

Active listening is a key component of the process of building an initial perception of the client's legal position and consists of confirming the client's narrative against your framework of understanding, asking appropriate follow-up questions and summarising your understanding by reflecting back to the client. ${ }^{113}$ Students should be fully attentive when listening to what and how clients say or what they don't say, ${ }^{114}$ listen to any goals, values and feelings attached thereto, ${ }^{115}$ analysing, as the client speaks, the information and appropriating it to their understanding of the situation. ${ }^{116}$ Failure to listen actively may result in clients not able to uncover all their concerns and, consequently, students' advice may be flawed. ${ }^{117}$

\section{Understanding clients, empathy and reflection}

Clinical legal educators will often, when teaching interviewing skills, accentuate a client-centred approach, highlighting the importance to listen to, and treat, clients as persons and not just as legal problems. ${ }^{118}$ This will reflect their social justice values, such as their rights to dignity

108 Ibid.

109 UWE supra 11 at 7

110 Ibid.

111 Also referred to as intentional listening. Lauchland \& Le Brun supra n52 at 47.

112 UWE supra $\mathrm{n} 11$ at 7

113 UWE supra $\mathrm{n} 11$ at 15-18.

114 Bolton states that 'even at the purely informational level, researchers claim that $75 \%$ of oral communication is ignored, misunderstood or quickly forgotten. Rarer still is the ability to listen for the deepest meanings in what people say.' Bolton People Skills (1987) 30.

115 Salinas supra $\mathrm{n} 11$ at 64 . Also see UWE supra n11 at 16,17. Students need to acknowledge emotions such as, for example, anger, distress, disappointment, outrage and anxiety. Students should acknowledge and confront strong feelings openly, as it may be a prerequisite for progressing with the client's case.

116 UWE supra n11 at 15.

117 Ibid.

118 ACLE supra n7 at 110 . 
and equality. ${ }^{119}$ Students must pay attention to how clients feel about their legal problems, their values and emotions associated therewith, and what their goals are in relation to their cases. ${ }^{120}$ Empathic responses and reflection, ${ }^{121}$ as active listening, strengthen already established trust, rapport and professional relationships. ${ }^{122}$ In teaching these skills as part of CLE the students' 'capacity for self-direction is dependent on their ability to be self-aware and to reflect on the implications of their experiences for future action. ${ }^{123}$ It is the students' ability to reflect, and then to alter their part in the process to produce a better outcome, which develops them as practitioners. ${ }^{124}$

\section{Empathy}

When 'just skills' are taught, the potential to explore the implications of students' use or non-use of a legal skill may prevent them from appreciating that their own values about the clients and their legal problems are reflected in the way they apply the skill. ${ }^{125}$ Legal problems are often not isolated, ${ }^{126}$ but are accompanied by a secondary narrative which may have some influence on the problem. ${ }^{127}$ Empathy is developed by effective interviewing skills. Students don't have to feel sorry for their clients to empathise. Students should be reminded that they may interview clients from across the social spectrum, some who may have acted contrary to their moral views. Students may not judge the clients, which must be reflected in their verbal and body language. Empathy includes their understanding of their clients' feelings and experiences. In empathising (not sympathising), the students will try not only to follow the client's narrative, but to understand it through their unique perspectives on their cases. An empathic student will try to understand the clients' difficulties and what may make them less difficult. ${ }^{128}$ Empathetic responses start with phrases like: 'I imagine' or 'It must be like'. ${ }^{29}$ Students should also pay attention to the client's confirmation of your empathic responses.

119 Ibid.

120 Salinas supra $\mathrm{n} 11$ at 135 . Empathising with clients will assist the attorney in understanding what the clients' legal problems are about and what motivate them. Reflecting these back to clients will assist in a more effective legal analysis.

121 Reflecting back to the clients the values and emotions attached to their stories, an essential element of active listening indicates to the clients an understanding of how they feel about what happened factually. This sets the stage for empathy and further establishes trust and rapport, encouraging client to open up. See Salinas supra n11 at 73-75.

122 Salinas supra n11 at 95, 188.

123 Quigley 'Seizing the disorienting moment: Adult learning theory and the teaching of social justice in law school clinics' 1995 Clinical Law Review 37, 50.

124 ACLE supra $\mathrm{n} 7$ at 163.

125 ACLE supra $\mathrm{n} 7$ at 109.

126 Du Plessis supra n3 at 124; De Klerk (2007) 97.

127 Salinas supra $\mathrm{n} 11$ at 87.

128 Salinas supra $\mathrm{n} 11$ at $92-94$.

129 Also see Lauchland \& Le Brun supra n52 at 50, 51. 


\section{Reflection 130}

Moon observes that reflection is a means of working on what we already know, ${ }^{131}$ a good starting point for the use of reflection within clinical teaching. ${ }^{132}$ What students recognise as a client's values during reflection may assist them during further interviews in exploring possible solutions or in defending the case. ${ }^{133}$ In the context of CLE, reflection may be used to develop a student's client skills, ${ }^{134}$ such as accurate factgathering. ${ }^{135}$ When students go beyond simply taking instructions, and consider how the facts may affect their clients, their process of reflection started. ${ }^{136}$ Students must reflect information back to the clients, through paraphrasing or summary, ${ }^{137}$ asking clarifying questions, allowing clients to correct any inconsistent, contradictory or misunderstood information. ${ }^{138}$ Students should also reflect on any emotional context and summarise emotional cues, as they indicate what clients think and feel about the legal problems. ${ }^{139}$

Summary and reflection should only start when clients start slowing down, or start repeating information, or when students' notes are so many that comprehension becomes difficult. The interview can be

130 See Lauchland \& Le Brun supra n52 at 51 - 54 for exercises on reflection during interviewing.

131 Moon Reflection in Learning and Professional Development: Theory \& Practice (1999) 1.

132 ACLE supra $n 7$ at 172-173. 'What the student knows prior to meeting with a client might be a collection of assumptions arising from the circumstances the client is in (that is, what legal issue they may have) and the "truths" that students might hold about those circumstances'.

133 Salinas supra $\mathrm{n} 11$ at 76.

134 For detailed discussions on reflection, see Moon supra n131 at 10, Dewey How We Think (1910), as cited in ACLE supra n7 at 157-160, Schön 'Educating the Reflective Legal Practitioner' 1995 Clinical Law Review 231. 249, Kolb Experiential Learning (1984)157-160, Gibbs Learning by doing: a guide to teaching and learning methods (1988), as cited in ACLE supra n7 at $157-160$.

135 ACLE supra n7 at 161-162. The authors use the example of 'the student who assumes a client who cannot recall detail must be lying; if the student has the opportunity to consider the experience of their client, including the client's personal history and circumstances, then the student may start to question this assumption - that their client is receiving counselling for posttraumatic stress, or that the client suffered a brain injury that interferes with memory or, simply, that the client fears losing' what he or she is claiming in the case 'due to the circumstances they are being asked to describe'.

136 Ibid.

137 Their summarisation can start with the phrases: 'It sounds like ...' 'It appears like ...', 'From what I gather ...', 'As I understand it ...' Salinas supra $\mathrm{n} 11$ at $179-180$.

138 Paraphrased facts may set the foundation of what the attorney regards as relevant. This indicates to the client that students have been listening and are gaining an understanding of the important facts. See Salinas supra n11 at $70-75$.

139 Salinas supra $\mathrm{n} 11$ at 181 . Words to use in summarising the emotional context are, for example: happy, frustrated, upset, troubled, angered, confused, determined or strengthened. 
paused to summarise for purposes of confirmation of the correctness of the facts presented. At this point during the interview students can transition between open-ended and close-ended questions to focus on specific details of the narrative. ${ }^{140}$

\section{Counseling skills}

Students should not shy away from talking to clients about their concerns, goals and values, ${ }^{141}$ remembering that the legal work impact on other people, organisations and companies. ${ }^{142}$ Clients who never consulted an attorney before may be particularly anxious and some basic counselling skills will be necessary. ${ }^{143}$ Part of students' interviewing skills training therefore is in accepting that, in practice, they will be attorneys and counsellors, and that they don't have to be experienced therapists to practice basic client counselling skills. ${ }^{144}$

\section{Advising clients}

Clinics, through CLE, contribute to developing the strategic planning skills of attorneys that will involve decision-making on whether to take or withhold action in achieving clients' goals. ${ }^{145}$ Students, although having to engage in the complexity of analysing the client's case where there often are multiple actors that may affect the outcome, ${ }^{146}$ they need to be cognisant of the fact that the client must decide what he or she wants the students to do, or what steps he or she wants to take. ${ }^{147}$

140 Idem at 185 .

141 Client counselling was identified as an applied practice skill for South Africa, see Steenhuisen supra n2 $266-279$.

142 Salinas supra $\mathrm{n} 11$ at 161.

143 Idem at 162-163. The amount of counseling skills that will be used, depend on clients' education and sophistication levels. Fewer such skills are required with more sophisticated clients. Also see Malkus supra n67 on understanding client's goals.

144 Salinas supra n11 at 159, 162-163. For detailed discussions on counselling skills in the legal environment see Redmount "An Inquiry Into Legal Counseling' The Journal of the Legal Profession 181 - 209 available at https:/ /www.law.ua.edu/pubs/jlp_files/issues_files/vol04/vol04art06.pdf (accessed 11-06-2018); Schoenfield 'Interviewing and counseling clients in a legal setting' 1977 Akron Law Review 313 - 331 available at https:// www.uakron.edu/dotAsset/f36260e3-b1 e8-4aef-8795-7b33b650a857.pdf (accessed 11-06-2018); Goodpaster 'The Human Arts of Lawyering: Interviewing and Counseling' 1975 Journal of Legal Education 5-52; Lauchland \& Le Brun supra n52 at 122 - 125; Chapman Essential legal skills: Interviewing and Counselling (1993), Chapter 5; Binder, Bergman \& Price Lawyers as counsellors: A Client-centred approach (1991) Chapters 15 22.

145 Sullivan, Colby, Welch Wegner, Bond \& Shulman Educating Lawyers: Preparation for the Profession of Law (2007) 26, 29.

146 Milstein 'Clinical legal education in the United States: In-House clinics, externships and simulations' 2001 Journal of Legal Education 375, 379.

147 Lauchland \& Le Brun supra n52 at 129, 130. 
Giddings indicates that the range of uncertainties that attorneys have to address will become evident when students are supervised effectively. ${ }^{148}$ Students will generally consult their clinicians before advising clients. A key objective of CLE is to assist students to develop the ability to deal with unstructured situations. ${ }^{149}$ This process involves supervision rather than direction: '[s]tudents need to invest in the quality of their decisions and this process is facilitated by having supervisors help students reflect on their experiences and not by displacing students as the lawyers for their clients.' 150

Clinicians should emphasise to students the importance of safeguarding client interests, and should talk through the processes used to provide advice that enables clients to make decisions. In advising clients, students must assume responsibility for their actions in a much more direct way than in other forms of legal education, recognising that their actions will influence the well-being of others. ${ }^{151}$

\section{Legal analysis and strategy}

Lauchland developed a problem-solving formula with the acronym CAFLIT to assist in analysing a client's case. ${ }^{152}$ CAFLIT stands for completing the analysis with a view to addressing the client's Concerns by summarising the Alleged Facts of the case, whereafter the applicable Law is explained to the client, articulating the legal Issues. Theories can now be developed on resolving the issues. ${ }^{153}$ Another legal analysis strategy, developed by Wade, ${ }^{154}$ uses the acronym MIRAT. The elements are selecting the Material facts and ascertaining the legal Issues whereafter the legal Rules are argued and Applied to reach a Tentative conclusion.

Students must, as a starting point, address the client's concerns, whereafter the facts must be summarised and the law applied. Legal issues must be clarified, some of which may differ from the client's concerns. The students must apply the problem-solving formula that they

148 'This includes uncertainty as to what has taken place and why, whether a client's account is likely to be accepted by relevant third parties, which legal doctrines are relevant to the issues facing the client, and how those doctrines are likely to apply'. See Giddings Promoting justice through clinical legal education (2013) 55-56.

149 Ibid.

150 Chavkin 'Experiential learning: A critical element of legal education in China (and elsewhere)' 2009 Pacific McGeorge Global Business and Development Law Journal 3, 17.

151 Giddings supra n1 48 at 69.

152 Lauchland \& Le Brun supra n52 at 104, using the acronym CAFLIT, indicating Concerns, Alleged Facts, Law, Issues and Theories.

153 For a full discussion see Lauchland \& Le Brun supra n52 at $104-113$.

154 For a full discussion see Wade 'Meet MIRAT: Legal reasoning fragmented into learnable chunks' 1990-1991 Legal Education Review 283 for the discussion of al alternative strategy with the acronym MIRAT, indicating Material facts, Issues, Rules/research, Argument/application and Tentative conclusion. 
developed through their CLE instruction on how to resolve the issues and address the client's concerns. Only then a strategy can be developed.

\section{Potential solutions - legal and non-legal options}

In proposing potential solutions to clients' problems, students should provide in layman's terms a detailed, yet easy-to-follow summary of their initial legal analysis. All options must be explored and the advantages or benefits, as well as the disadvantages or risks and the consequences must be discussed with the client. ${ }^{155}$ An approach which students may use, is to ask the client what he or she thinks the best or worst outcomes would be, setting parameters within which to discuss possible solutions. ${ }^{156}$ Students must not guarantee any results, cautioning the client that the case is at the interview stage and more information may be needed and research done to fully evaluate the case. ${ }^{157}$ Additional work may be outlined. ${ }^{158}$ Students must inform the client that, in the final instance, they remain the decision-makers. ${ }^{159}$

\section{Ending an interview}

Students must summarise the discussions and confirm actions that they and the clients need to take. ${ }^{160}$ The students must make sure that the clients have no further queries, whereafter they should thank the clients and confirm that a written summary of their matter will be sent to them within a specified time. ${ }^{161}$

\section{Meeting learning outcomes}

In paragraph 2, skills and outcomes in the CLE programme, when focusing on interviewing, were discussed. A study on CLE outcomes, comprising multiple international jurisdictions, ${ }^{162}$ compares favourably with the outcomes, with specific sub-goals, ${ }^{163}$ stated for South African university law clinics, ${ }^{164}$ as they pertain to interviewing skills. These are: professional responsibility, legal ethics, judgment and analytical abilities,

155 Lauchland \& Le Brun supra n52 at 119, 122-123.. The students should attempt to imagine how clients see their concerns and establish priorities of the options to be taken.

156 Ibid.

157 Salinas supra $n 11$ at $112,138,142$. When framing the legal analysis to the client, the following words are suggested: 'generally', 'usually', 'typically' or 'often'.

158 During the analysis phase of the interview, further documents for review and other individuals to be interviewed can be identified. Salinas supra n11 at 143.

159 Ibid 143.

160 Lauchland \& Le Brun supra n52 at 135-139.

161 Salinas supra $\mathrm{n} 11$ at 154, UWE supra 11 at 24.

162 For a full discussion of the study see Du Plessis supra n3 at 31-53.

163 Steenhuisen supra n2 266-279.

164 For a full discussion see Du Plessis supra n3 at 31-53. 
understanding process and procedure, synthesis, social awareness, legal services to the community, applied practice skills, consultation skills, recognition of relevant facts and applicable law, understanding strategy, tactics and decision making, draft legal documents, client counseling, negotiation, legal research and reflection.

For detailed outcomes specifically relevant to interviewing skills, the possible learning outcomes for CLE as proposed in Australian Best Practices are beneficial. ${ }^{165}$ Students should be able to demonstrate:

critical analyses of legal concepts through reflective practice; an ability to practise 'lawyering' skills; developed interpersonal skills, emotional intelligence and self-awareness of their own cognitive abilities and values; an understanding, and appropriate use, of the dispute resolution continuum; ${ }^{166}$ an awareness of lawyering as a professional role in the context of wider society and of the importance of professional relationships, ${ }^{167}$ developing a personal sense of responsibility, resilience, confidence, self-esteem and, particularly, judgment; a consciousness of multi-disciplinary approaches to clients' dilemmas - including recognition of the non-legal aspects of clients' problems; a developing preference for an ethical approach and an understanding of the impact of that preference in exercising professional judgment; a consolidated body of substantive legal knowledge, and knowledge of professional conduct rules and ethical practice; and an awareness of the social issues of justice, power and disadvantage and an ability to critically analyse entrenched issues of justice in the legal system. ${ }^{168}$

It is submitted that, should students follow the guidelines and instructions as set out herein, the proposed outcomes, as applicable to interviewing skills, will be met.

\section{Conclusion}

In its most complex and analytical form, skills teaching, which includes interviewing skills, can be seen as 'truly complementary to a clinic's social justice mission, enabling students to suspend judgment, to communicate and listen across differences and to explore solutions creatively'. ${ }^{169}$ Schön correctly stated that 'this privileging of the knowledge over its application in practice was an inversion of the natural

165 Evans et al Australian Clinical Legal Education: Designing and Operating a Best Practice Clinical Program in an Australian Law School (2017), available at www.jstor.org/stable/j.ctt1q1crv4 (accessed 04-04-2018). For a full discussion see ACLE supra $\mathrm{n} 7$ at 81-82.

166 Negotiation, mediation, collaboration, arbitration and litigation.

167 Including the imperatives of corporate social responsibility, social justice and the provision of legal services to those unable to afford them.

168 ACLE supra $\mathrm{n} 7$ at 81-82.

169 Lopez 'Learning through service in a clinical setting: the effect of specialization on social justice and skills training' 2000 Clinical Law Review 307; also see Bryant supra n43 at 33. 
order of things because the delivery of high-quality work for the client is the reason why we have professions in the first place'. ${ }^{170}$

In discussing the teaching of interviewing skills, emphasis was placed on student preparation, which included working with preconceptions and assumptions, ${ }^{171}$ and counselling skills. ${ }^{172}$ It was indicated that, during the interview students, who are questioning and taking notes, ${ }^{173}$ are on a fact-gathering hunt when listening to and understanding the client's story. ${ }^{174}$ In discussing a number of questioning techniques, it was indicated that general education literature supports the premise that the way questions are sequenced may be more important in promoting understanding than the cognition level of the question, ${ }^{175}$ and that periodic summaries serve to confirm students' understanding of the cases. ${ }^{176}$ It was shown that the strength of the message from non-verbal cues is many times stronger than that from words alone. ${ }^{177}$ Students should be instructed on behaviour that may create barriers between them and their clients, ${ }^{178}$ the value of mirroring their clients' behaviour, ${ }^{179}$ and prosody. ${ }^{180}$ These are clusters of behaviours to be interpreted within context. ${ }^{181}$ It was illustrated that active listening skills consist of three components, ${ }^{182}$ which include empathy and counselling skills. ${ }^{183}$ It was indicated that empathy is developed by effective interviewing skills and will reflect students' social justice values.

Clinicians, in student training, should accentuate a client-centred approach whereby clients are listened to and treated as persons and not just as legal problems. ${ }^{184}$ An Australian professor, in response to the Carnegie Report, observed: 'If students receive the message that

170 Neumann 'Donald Schön, The Reflective Practitioner, and the Comparative Failures of Legal Education' 1999 Clinical Law Review 401-426. The Carnegie Report in the United States called for an integration of realistic and real-life lawyering experiences throughout the curriculum, see Sullivan supra 145.

171 Salinas supra n11 at 21,175; UWE supra n11 at 8; Tremblay supra n11 at 373.

172 Salinas supra $\mathrm{n} 11$ at 2016:161-163.

173 Available at http://lsc.cornell.edu/study-skills/cornell-note-taking-system/; https://lawyerist.com/lawyers-take-notes-hand/ UWE supra n11 at 24; Mazzone: https://www.attorneyatwork.com/tech-tips-note-taking-digitaldictation-apps/ (accessed 04-04-2018).

174 Salinas supra $\mathrm{n} 11$ at 129.

175 Brophy \& Good supra n76 at 189-193.

176 Salinas supra $\mathrm{n} 11$ at 132.

177 UWE supra $n 11$ at 7.

178 Salinas supra $\mathrm{n} 11$ at $176-177$.

179 Ibid.

180 UWE supra 111 at 7.

181 Ibid. This will include a discussion on prosody.

182 '(a) checking what the client is saying against your frameworks of understanding; (b) following up points that you hear by appropriate questioning; and (c) checking that you have understood by summarising and reflecting back what you have heard'. See UWE supra n11 at 15-18.

183 Salinas supra $\mathrm{n} 11$ at 159-161.

184 ACLE supra $\mathrm{n} 7$ at 109-110. 
intellectual capacities are prized beyond all else, then they will rely upon that in their future behaviour as legal practitioners. They will tend to be unconcerned about the impact their behaviour has on others'. ${ }^{185}$ The students must reflect on what the client said and their understanding of what the clients are going through, either by paraphrasing some of the facts or by way of summary. ${ }^{186}$ In discussing a selection of theorists, ${ }^{187}$ Moon indicated that 'reflection is a means of working on what we already know' ${ }^{188}$ In CLE, reflection may be used to develop students' client skills, ${ }^{189}$ where they go beyond simply taking instructions and gathering facts, but also consider how the facts may affect their clients. ${ }^{190}$ In discussing legal analysis and strategy, ${ }^{191}$ it was indicated that potential solutions may be found through legal and non-legal options. ${ }^{192}$ It was also shown that the proposed CLE outcomes, applicable to interviewing skills, were met. In teaching [interviewing] skills in CLE, it is the students' 'capacity for self-direction [which] is dependent on their ability to be selfaware and to reflect on the implications of their experiences for future action, ${ }^{, 193}$ and then to alter their part in the process to produce a better outcome, which develops them as practitioners. ${ }^{194}$

It was indicated that, although clinicians are present or generally available in the clinic while students are conducting interviews with clients, they are seldom party to such interviews. ${ }^{195}$ Student training and instruction in this essential skill which, in synergy incorporate a number of other identified skills, ${ }^{196}$ is therefore essential, particularly as the information gained from the client during the interview constitutes the facts of the legal problem. It was however indicated that the lack of direct supervision during interviews is not insurmountable. This article may form the basis for creating a student manual on interviewing skills. CLE instruction at many of the South African university law clinics includes plenary- and tutorial sessions. ${ }^{197}$ This article may further serve as an outline for plenary instruction on interviewing skills, which may be

185 Davis 2008, as quoted in ACLE supra n7 at 2017:165.

186 Salinas supra n11 at 70-75. During this reflection students may ask clarifying questions, allowing clients to correct any misunderstood information.

187 Dewey helps us to understand how we think and Schön, Kolb and Gibbs suggest the processes by which those ways of thinking might work together to produce new insights and action. See ACLE supra n7 at 157-160.

188 Moon supran131 at 1 .

189 Active listening ensures that students become aware of their clients' concerns and anxieties, whilst obtaining the information required to advise them. Failure to listen actively may result in clients not able to uncover all their concerns and consequently students' advice may be flawed. See UWE supra $\mathrm{n} 11$ at 15 .

190 ACLE supra $\mathrm{n} 7$ at 161-162.

191 Salinas supra $\mathrm{n} 11$ at 98, 110-112, 138, 142.

192 Idem at $145-150$.

193 See Quigley supra n123 at 37, 50.

194 ACLE supra $n 7$ at 163.

195 See discussion in para 1 .

196 See discussion in para 2.

197 Du Plessis supra n3 at $40-44$ 
reinforced during tutorial sessions students attend with their clinicians, ${ }^{198}$ further allowing clinicians to consider interviewing skills as an assessable component of the CLE course. ${ }^{199}$

198 Du Plessis supra $n 3$ at 26 - 30, indicating that the clinical pedagogy should comprise of the clinical experience, the classroom component and the tutorial component.

199 See Du Plessis supra n3 at $122-132$ on the assessment of interviewing skills. 